\title{
Anti-Inflammatory and Analgesic Effect of Arachic Acid Ethyl Ester Isolated from Propolis
}

\author{
Sélestin Dongmo Sokeng, ${ }^{1}$ Emmanuel Talla, ${ }^{2}$ Paul Sakava, ${ }^{3}$ \\ Michel Archange Fokam Tagne $\mathbb{D}^{1},{ }^{1}$ Celine Henoumont, ${ }^{4}$ Laurent Sophie $\mathbb{D},{ }^{4}$ \\ Joseph Tanyi Mbafor, ${ }^{3}$ and Fernand-Nestor Tchuenguem Fohouo ${ }^{1}$ \\ ${ }^{1}$ Department of Biological Sciences, Faculty of Science, University of Ngaoundéré, P.O. Box 454, Ngaoundéré, Cameroon \\ ${ }^{2}$ Department of Chemistry, Faculty of Sciences, University of Ngaoundéré, P.O. Box 454, Ngaoundéré, Cameroon \\ ${ }^{3}$ Department of Organic Chemistry, Faculty of Sciences, University of Yaoundé I, P.O. Box 812 Yaoundé, Cameroon \\ ${ }^{4}$ Laboratory of NMR and Molecular Imaging, Department of General, Organic Chemistry and Biomedical, University of Mons, \\ B-7000 Mons, Belgium
}

Correspondence should be addressed to Michel Archange Fokam Tagne; fm_archange@yahoo.fr

Received 16 September 2019; Revised 30 March 2020; Accepted 8 April 2020; Published 5 May 2020

Academic Editor: Nilufer Yuksel

Copyright (C) 2020 Sélestin Dongmo Sokeng et al. This is an open access article distributed under the Creative Commons Attribution License, which permits unrestricted use, distribution, and reproduction in any medium, provided the original work is properly cited.

\begin{abstract}
Inflammatory diseases are a real public health problem worldwide. Many synthetic drugs used in the treatment of inflammatory diseases such as steroidal anti-inflammatory drugs, nonsteroidal anti-inflammatory drugs (NSAIDs) and immunosuppressive drugs have harmful side effects. However, there are natural products like propolis, which is traditionally used in the treatment of pain. The objective of this work was to evaluate the anti-inflammatory and analgesic activities of the ethyl ester of arachic acid, a compound isolated from Cameroonian propolis. The ethyl ester of arachic acid was isolated by chromatography of the ethanolic extract of propolis harvested at Tala-Mokolo (Far North Region of Cameroon) and identified by nuclear magnetic resonance (NMR) spectra and the ${ }^{1} \mathrm{H}-{ }^{1} \mathrm{H}$ correlated spectroscopy. The anti-inflammatory and analgesic properties of oral administration of arachic acid ethyl ester $(12.5,25.0$, and $50.0 \mathrm{mg} / \mathrm{kg} \mathrm{bw})$ were evaluated using carrageenan-induced paw edema, xyleneinduced ear edema, cotton pellets-induced granuloma formation, and hot plate test in rat. Arachic acid ethyl ester produced maximum inhibition at $50.0 \mathrm{mg} / \mathrm{kg}$ for carrageenan-induced paw edema (62.5\%), xylene-induced ear edema (54.5\%), cotton pellet-induced granuloma (47.4\%), and increased mean latency for hot plate test in rats. These results show clearly that the arachic acid ethyl ester has acute and chronic anti-inflammatory properties as well as central analgesic properties. This justifies the use of propolis in the treatment of pain in traditional medicine.
\end{abstract}

\section{Introduction}

Rheumatic diseases associated with inflammatory diseases are very common worldwide and constitute a major public health problem. Inflammatory diseases are mammalian tissue pathologies caused by various agents, including infectious microorganisms, toxic chemicals, physical lesions, or tumor growth [1]. During the inflammatory process, injured tissue cells, phagocytes, lymphocytes, and mast cells secrete mediators of inflammation such as histamine, kinins, prostaglandins, complement, and lymphokines. Inflammation is a nonspecific body's response to pathogens. Acute inflammation is manifested by pain, heat, redness, swelling, and loss of function [2]. Inflammatory diseases can be acute or chronic. The body's initial response to inflammatory agents is acute inflammation characterized by increased movements of leukocytes (granulocytes) and plasma from the blood to injured tissues. During acute inflammation, several biochemical mechanisms involving the local vascular system, the immune system, and various cells occur within the injured tissue. Long-term inflammation, also known as chronic inflammation, is characterized by the simultaneous 
destruction and healing tissues, resulting in a gradual change in the type of cells present at the site of inflammation [3]. Many synthetic chemicals such as steroidal drugs, nonsteroidal anti-inflammatory drugs (NSAIDs), and immunosuppressive drugs available for the treatment of inflammatory diseases have some harmful side effects [4]. Propolis is a crude compound of beehive made by bees from resin harvest to several plants [5]. It is used in folk medicine as antibiotic [6], antiviral [7], antioxidant [5], and anti-inflammatory [8]. The present study was undertaken to evaluate the antiinflammatory and analgesic activities of arachic acid ethyl ester (AAEE) isolated from propolis in rats.

\section{Materials and Methods}

\subsection{Biological Material}

\subsubsection{Arachic Acid Ethyl Ester Isolation and Identification}

(1) Propolis Collection. Propolis was collected in January 2012 from Tala-Mokolo (Far North Region of Cameroon), an agroecological zone, and was identified by a Beekeeper, Damatal.

(2) Propolis Extraction. Dried powdered propolis (405 g) was extracted three times by maceration at room temperature with ethanol $(\mathrm{EtOH})(3 \times 6 \mathrm{~L})$ for 72 hours. The supernatants were filtered and evaporated under vacuum by means of a rotary evaporator (Büch, 461) to obtain a dried brown extract $(75 \mathrm{~g})$.

(3) Isolation and Identification. The ethanol extract (75 g) was subjected to silica gel column chromatography $(\varnothing$ $0.063-0.200 \mathrm{~mm}, 650 \mathrm{~g}$ ) and eluted with the mixture nhexane-ethyl acetate (EtOAc) and EtOAc-methanol $(\mathrm{MeOH})$ in order to increase polarity (0-100\%) to yield a total of 309 fractions of $300 \mathrm{~mL}$ each. These fractions were combined on the basis of thin-layer chromatography (TLC) analysis in fifteen major fractions $\left(\mathbf{F}_{\mathbf{1}}-\mathbf{F}_{\mathbf{1 5}}\right)$. Fraction $\mathbf{F}_{\mathbf{1}}$ was purified by silica gel column chromatography $(\varnothing \quad 0.063-0.200 \mathrm{~mm}$, $75 \mathrm{~g}$ ) under isocratic elution with the mixtures n-hexaneEtOAc and EtOAc-MeOH with gradient polarity (0-100\%) as eluents. After filtration and crystallization, $1300 \mathrm{mg}$ of the white crystal was obtained and indexed $\mathrm{PEN}_{4}$ and then subjected to spectral analysis. ${ }^{1} \mathrm{H}$ and ${ }^{13} \mathrm{C}$ nuclear magnetic resonance (NMR) spectra and ${ }^{1} \mathrm{H}-{ }^{1} \mathrm{H}$ correlated spectroscopy (COSY), distortionless enhancement by polarization transfer (DEPT), heteronuclear single quantum coherence (HSQC), and heteronuclear multiple bond correlation (HMBC) spectra were recorded from Bruker Advance DMX $400 \mathrm{MHz}$ spectrometers.

The ${ }^{13} \mathrm{C}$-NMR spectrum (Figure 1 ) and ${ }^{13} \mathrm{C}$-DEPT 135 spectrum (Figure 2) indicate 22 carbons: two methyls into final position with $\delta_{\mathrm{C}} 15.2$ (C-20 and C-2' $)$; eighteen methylenes between $25.04 \mathrm{ppm}$ and $34.41 \mathrm{ppm}$; one oxygenated methyl with $\delta_{\mathrm{C}} 64.37\left(\mathrm{C}-1^{\prime}\right)$; and one quaternary carbon with $\delta_{\mathrm{C}} 173.96(\mathrm{C}-1)$, ascribable to the carbon of the function ester. Moreover, the ${ }^{1} \mathrm{H}-\mathrm{NMR}$ spectrum (Figure 3 ) showed

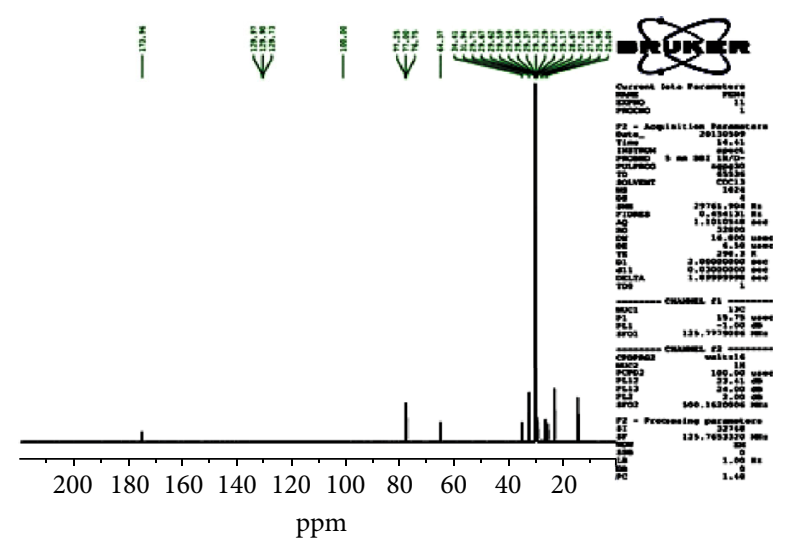

Figure 1: ${ }^{13} \mathrm{C}$ NMR spectrum $(\mathrm{CDCl} 3,125 \mathrm{MHz})$ of $\mathrm{PEN}_{4}$.

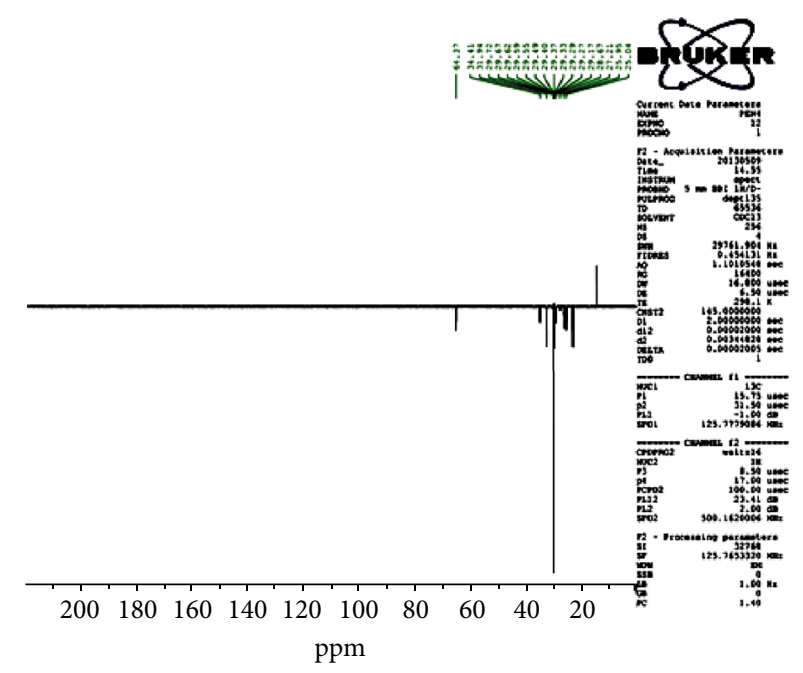

Figure 2: ${ }^{13} \mathrm{C}$ DEPT 135 spectrum $(\mathrm{CDCl} 3,125 \mathrm{MHz})$ of $\mathrm{PEN}_{4}$.

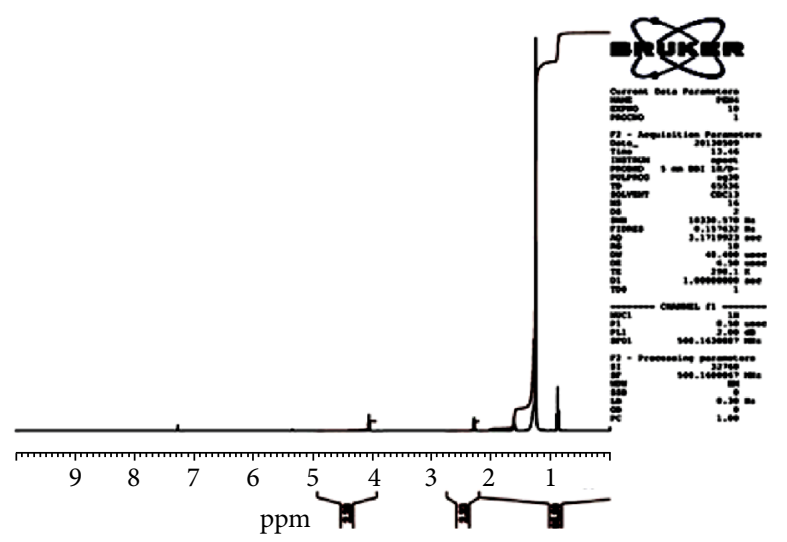

Figure 3: ${ }^{1} \mathrm{H}$ NMR spectrum $(\mathrm{CDCl} 3,500 \mathrm{MHz})$ of $\mathrm{PEN}_{4}$.

a triplet with $\delta_{\mathrm{H}} 0.88$ ascribable to the protons of the two groupings methyls, proton of methyl in $\alpha\left(\delta_{\mathrm{H}} 2.26 / \mathrm{H}-2\right)$ and proton of methyl in $\beta\left(\delta_{\mathrm{H}} 1.58 / \mathrm{H}-3\right)$ of the function ester, and protons of O-methyl with $\delta_{\mathrm{H}} 4.1\left(\mathrm{H}-1^{\prime}\right)$, and an aliphatic methyl long chain have $\delta_{\mathrm{H}} 1.35\left(\mathrm{CH}_{2}\right)_{16}$. 

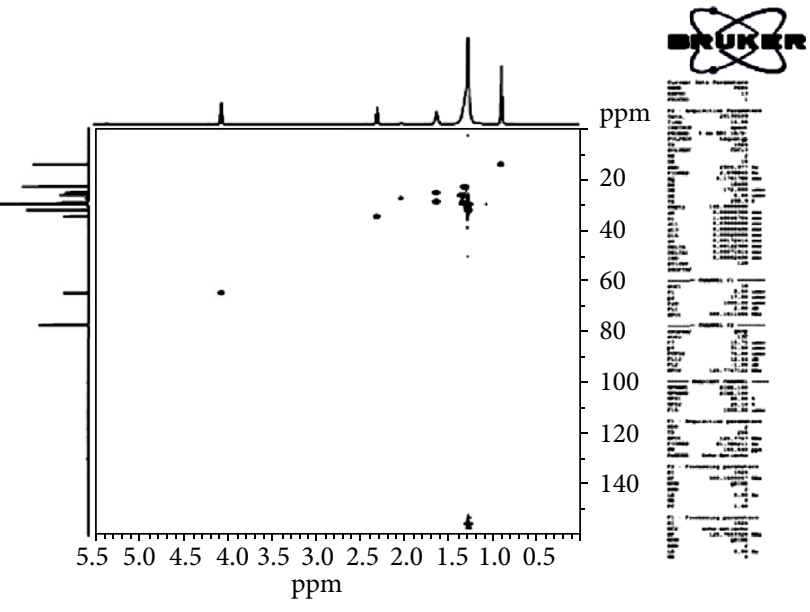

FIgURE 4: HSQC spectrum $(\mathrm{CDCl} 3,125 \mathrm{MHz})$ of $\mathrm{PEN}_{4}$.

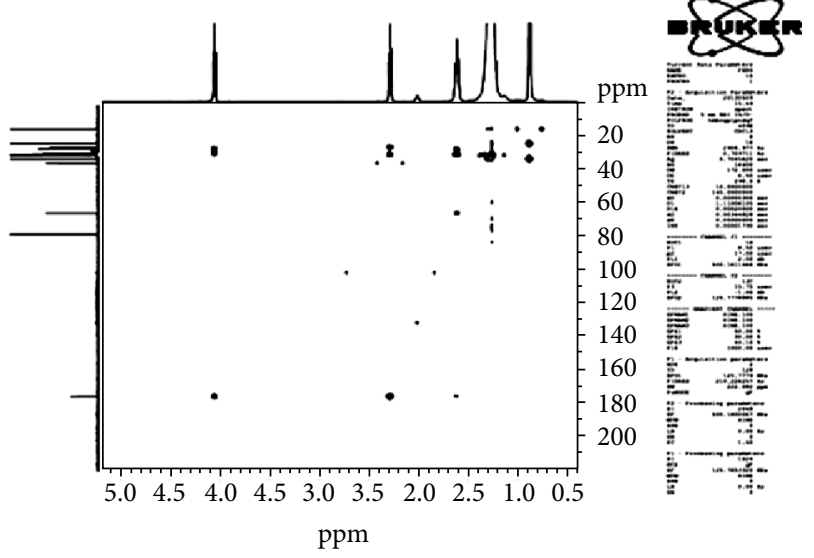

Figure 5: HMBC spectrum $(\mathrm{CDCl} 3,125 \mathrm{MHz})$ of $\mathrm{PEN}_{4}$.

The HSQC experiment showed the protons with $\delta_{\mathrm{H}} 4.1$ $\left(\mathrm{H}-1^{\prime}\right)$ that were related to carbon with $\delta_{\mathrm{C}} 64.37\left(\mathrm{C}-1^{\prime}\right)$, the protons in $\alpha\left(\delta_{\mathrm{H}} 2.26 / \mathrm{H}-2\right)$ of the function ester related to carbon with $\delta_{\mathrm{C}} 34.41(\mathrm{C}-2)$, the protons in $\beta\left(\delta_{\mathrm{H}} 1.58 / \mathrm{H}-3\right)$ of the function ester related to carbon with $\delta_{\mathrm{C}} 25.95$ (C-3), and the protons with $\delta_{\mathrm{H}} 0.88$ attached to carbons with $\delta_{\mathrm{C}}$ 15.2 (Figure 4).

The HMBC spectrum (Figure 5) showed a correlation between protons of the O-methyl $\left(\mathrm{H}-1^{\prime}\right)$ and carbons with $\delta_{\mathrm{C}} 173.96(\mathrm{C}-1), \delta_{\mathrm{C}} 25.95(\mathrm{C}-3)$, protons in $\alpha\left(\delta_{\mathrm{H}} 2.26 / \mathrm{H}-2\right)$ and $\beta\left(\delta_{\mathrm{H}} 1.58 / \mathrm{H}-3\right)$ of the function ester, and protons of two methyls and carbons with $\delta_{\mathrm{C}} 25.04(\mathrm{C}-19)$ and $\delta_{\mathrm{C}}$ 34.41 (C-2), respectively.

The COSY spectrum (Figure 6) showed correlations between protons of the O-methyl $\left(\delta_{\mathrm{H}} 4.1 / \mathrm{H}-1^{\prime}\right)$ and protons in $\beta\left(\delta_{\mathrm{H}} 1.58 / \mathrm{H}-3\right)$ of the function ester, protons in $\beta\left(\delta_{\mathrm{H}}\right.$ $1.58 / \mathrm{H}-3)$ and $\alpha\left(\delta_{\mathrm{H}} 2.26 \mathrm{H}-2\right)$ of the function ester, protons with $\delta_{\mathrm{H}} 0.88 / \mathrm{H}-20$, and protons with $\delta_{\mathrm{H}} 1.35 / \mathrm{H}-19$.

A combination of NMR, DETP, COSY, HSQC, and HMBC spectral data, compared with those of the literature $[9,10]$, makes it possible to give to the made-up $\mathrm{PEN}_{4}$, the structure which is that of the ethyl arachidate or arachic/arachidic acid ethyl ester (AAEE) with a formula $\mathrm{C}_{22} \mathrm{H}_{44} \mathrm{O}_{2}$

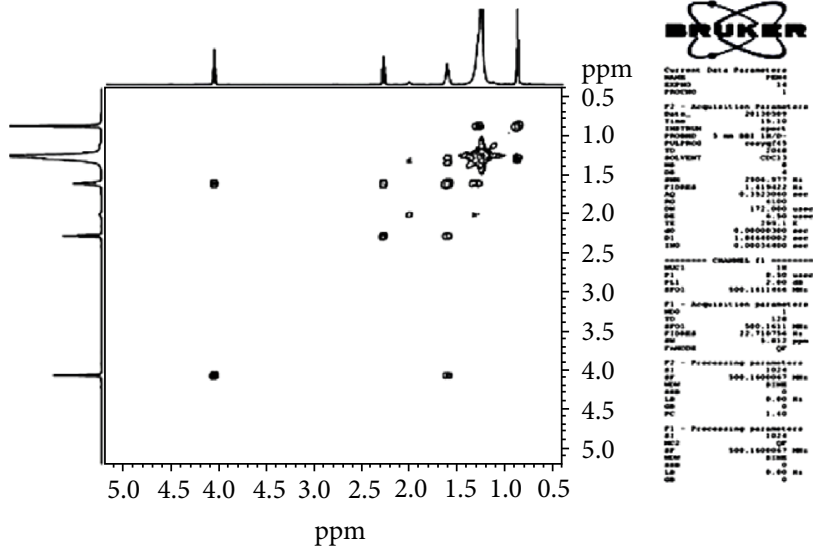

Figure 6: COSY spectrum of $\mathrm{PEN}_{4}$.

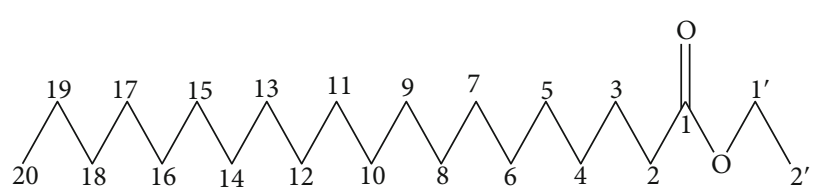

FIgURE 7: Ethyl arachidate or arachic acid ethyl ester (AAEE) structure.

(Figure 7). Within the limit of our knowledge, the compound is insulated for the first time from the propolis.

Prior to the oral administration, AAEE was dissolved in refined palm oil so that each animal received less than $10 \mathrm{~mL} / \mathrm{kg}$ body weight solution.

2.1.2. Animals. Wistar albino rats $(150-180 \mathrm{~g})$, obtained from the breeding house of the University of Ngaoundéré, were allowed water and food ad libitum. The rats were kept in standard polypropylene cages (five/cage). All animals were acclimatized for one week under laboratory environmental conditions (temperature and dark/light cycle) before the start of the study. In vivo experimental treatments of animals have been carried out in accordance with the European Union guidelines on Animal Care (CEE Council 86/609) [11] that was adopted in Cameroon by the Institutional Committee of the Ministry of Scientific Research and Innovation.

\subsection{Anti-Inflammatory Test}

2.2.1. Carrageenan-Induced Paw Edema. The carrageenaninduced paw edema model rat used has been previously described by the Winter et al. method [12]. Briefly, 25 rats were randomly divided into five groups of five rats each and treated as follows:

(1) Group 1 (negative control group: NC) received palm oil as vehicle $(10 \mathrm{~mL} / \mathrm{kg})$

(2) Groups 2 to 4 (test groups), respectively, received arachic acid ethyl ester $12.5 \mathrm{mg} / \mathrm{kg}$ bw (AAEE12.5), arachic acid ethyl ester $25 \mathrm{mg} / \mathrm{kg}$ bw (AAEE25), and arachic acid ethyl ester $50 \mathrm{mg} / \mathrm{kg}$ bw (AAEE50) 
(3) Group 5 (positive control group: Dexa5) received dexamethasone $5 \mathrm{mg} / \mathrm{kg}$ bw as reference drugs

One hour after this treatment, inflammation was induced by subplantar injection of $0.1 \mathrm{~mL}$ of $1 \%$ suspension of carrageenan (Sigma Chemical Co., St Louis, USA) in normal saline $(9 \%)$, in the right hind paw of each rat. Edema formations were measured immediately prior to the injection of carrageenan and thereafter at intervals of 1 for $6 \mathrm{~h}$. The inhibition of edema was calculated according to the following formula [3]:

Percentage inhibition $=\frac{\left(C_{t}-C_{0}\right) \text { Untreated }-\left(C_{t}-C_{0}\right) \text { Treated }}{\left(C_{t}-C_{0}\right) \text { Untreated }} \times 100$,

where $C_{t}$ means the paw circumference for each group at time $t$ and $C_{0}$ means the paw circumference for each group before carrageenan injection.

2.2.2. Xylene-Induced Ear Edema. Five groups of five normal rats each received per os one hour before xylene application, arachic acid ethyl ester (AAEE) at dose $12.5 \mathrm{mg} / \mathrm{kg}$ (AAEE12), $25 \mathrm{mg} / \mathrm{kg}$ (AAEE25), and $50 \mathrm{mg} / \mathrm{kg}$ (AAEE50) body weight, dexamethasone $2.5 \mathrm{mg} / \mathrm{kg}$ (Dexa5) as a positive control or palm oil $(10 \mathrm{~mL} / \mathrm{kg})$ as a negative control.

Ear edema was induced by applying $0.03 \mathrm{~mL}$ of xylene to the posterior and anterior surfaces of the right ear of each rat. The left ear did not receive xylene and was considered as control. The animals were then anesthetized with diethyl ether, and the right and left ears were perforated $(9 \mathrm{~mm}$ in diameter) using a borer. Each ear punch was weighed and the differences between the weight of the right ear and the left ear punches of each rat were calculated [4].

2.2.3. Cotton Pellet-Induced Granuloma Formation in Rat. Five groups of five normal rats each were anesthetized with diethyl ether. Sterilized cotton pellet $(20 \mathrm{mg})$ was then surgically implanted subcutaneously in both shaved axilla regions of rats using small incisions. The control group (Group 1) received orally refined palm oil $(10 \mathrm{~mL} / \mathrm{kg})$, the test groups (Group 2, Group 3, and Group 4) received orally arachic acid ethyl ester $12.5,25$, and $50 \mathrm{mg} / \mathrm{kg}$ bw, respectively, and the fifth group received oral morphine at $5 \mathrm{mg} / \mathrm{kg}$ body weight, and this was done once daily for a period 7 consecutive days. At the eighth day, cotton pellets were dissected out under ether anesthesia, cleaned of extraneous tissue, weighed, and dried at $60^{\circ} \mathrm{C}$ to a constant weight. The mean weight for different groups was determined. The measurement of granuloma formation was appreciated by increasing the dry weight of pellets [13].

2.3. Analgesic Test. Five groups of five rats each were used to study the analgesic activity of arachic acid ethyl ester by a hot plate test (pain model). The control group (Group 1) received refined palm oil $(10 \mathrm{~mL} / \mathrm{kg})$, the test groups (Group 2, Group 3 , and Group 4) received arachic acid ethyl ester 12.5, 25, and $50 \mathrm{mg} / \mathrm{kg}$ bw, respectively, and group five received morphine at $2.5 \mathrm{mg} / \mathrm{kg}$ bw. The rats were placed on Eddy's hot plate and maintained at a temperature of $55 \pm 0.5^{\circ} \mathrm{C}$. Hot plate laten-

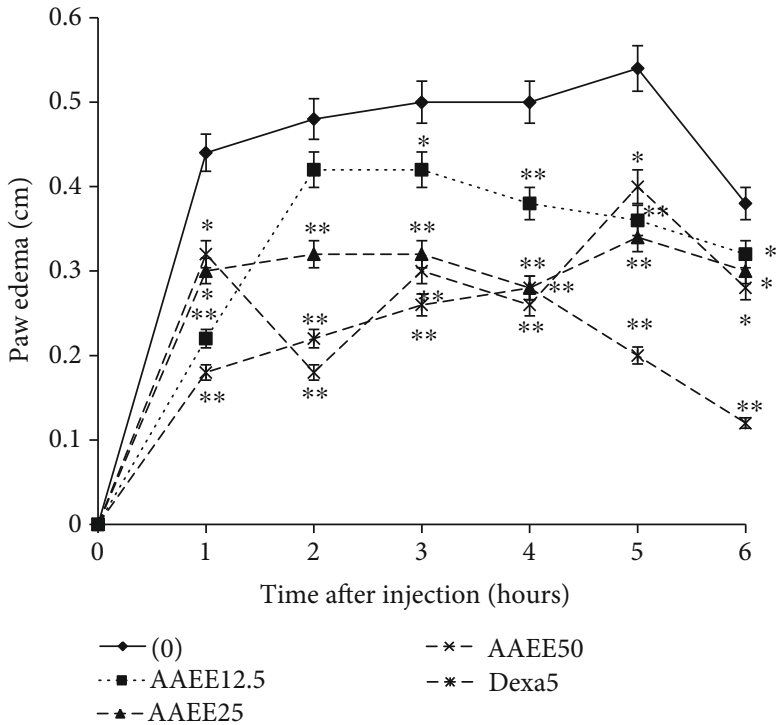

FIgure 8: Effect of arachic acid ethyl ester (AAEE) on the carrageenan-induced paw edema in rat. Values are expressed as mean \pm SEM $(n=5)$. Significant difference: ${ }^{*} p<0.05$ and ${ }^{* *} p<$ 0.01 compared with control at the same time point. Dexa5: dexamethasone.

cies were measured at $0,0.5,1,2,3,4,5$, and 6 hours after treatment [14]. Animals were delayed not more than $30 \mathrm{sec}$ onds every time on the hot plate [15]. The analgesic activity was calculated according to formula

$$
\mathrm{PA}(\%)=\frac{(\text { MTR treated })-(\text { MTR untreated })}{(\text { MTR treated })} \times 100,
$$

where MTR means the time of reaction and PA the percentage of analgesic activity.

2.4. Statistical Analysis. Data were expressed as mean \pm standard error of mean $(\overline{\mathrm{X}} \pm \mathrm{SEM})$. The data were analyzed by one-way ANOVA followed by Dunnett's $t$-test using the computerized GraphPad InStat 3.05 versions (GraphPad Software, USA). Differences were considered significant when $p<0.05$.

\section{Results}

3.1. Effect of Arachic Acid Ethyl Ester (AAEE) on Carrageenan-Induced Paw Edema in Rats. The injection of carrageenan resulted in an increase of paw edema between the first hour $(0.44 \mathrm{~cm})$ and the fifth hour $(0.54 \mathrm{~cm})$ but falls at the sixth hour $(0.38 \mathrm{~cm})$ in the control group. These values decreased in the treated group over time. They decreased significantly $(p<0.01)$ from the first hour to the sixth hour in all treated groups (Figure 8). Maximum inhibitions were $62.50 \%$ in the group treated with AAEE $50 \mathrm{mg} / \mathrm{kg}$ bw at the second hour and $68.22 \%$ in the group treated with dexamethasone $5 \mathrm{mg} / \mathrm{kg}$ bw.

3.2. Effect of Arachic Acid Ethyl Ester (AAEE) on XyleneInduced Ear Edema in Rat. In the untreated group (control) 
TABLE 1: Effect of arachic acid ethyl ester (AAEE) on xyleneinduced ear edema in rat.

\begin{tabular}{lccc}
\hline Group & Treatment & $\begin{array}{c}\text { Weight of ear } \\
\text { edema }(\mathrm{mg})\end{array}$ & \% inhibition \\
\hline Control & PO $(10 \mathrm{~mL} / \mathrm{kg})$ & $6.6 \pm 0.3$ & \\
Dexamethasone & $5 \mathrm{mg} / \mathrm{kg}$ & $2.8 \pm 0.1^{* *}$ & 57.6 .6 \\
& $12.5 \mathrm{mg} / \mathrm{kg}$ & $4.0 \pm 0.2^{*}$ & 39.4 \\
AAEE & $25 \mathrm{mg} / \mathrm{kg}$ & $3.2 \pm 0.1^{* *}$ & 51.5 \\
& $50 \mathrm{mg} / \mathrm{kg}$ & $3.0 \pm 0.1^{* *}$ & 54.5 \\
\hline
\end{tabular}

Values are expressed as mean $\pm \operatorname{SEM}(n=5)$. Significant difference: ${ }^{*} p<0.05$ and ${ }^{* *} p<0.01$ compared with control. PO: palm oil.

rats, ear edema induced by xylene was $6.6 \pm 0.3 \mathrm{mg}$. In rats treated with the AAEE solution at doses of $12.5 \mathrm{mg} / \mathrm{kg}$, $25 \mathrm{mg} / \mathrm{kg}$, and $50 \mathrm{mg} / \mathrm{kg}$ bw or treated with dexamethasone $5 \mathrm{mg} / \mathrm{kg}$ bw, xylene-induced ear edema significantly reduced $(p<0.01)$ and were, respectively, $4.0 \pm 0.2 \mathrm{mg}, 3.2 \pm 0.1 \mathrm{mg}$, $3.0 \pm 0.1 \mathrm{mg}$, and $2.8 \pm 0.1 \mathrm{mg}$ (Table 1). Maximum inhibitions were $54.55 \%$ in the group treated with AAEE $50 \mathrm{mg} / \mathrm{kg}$ bw at the second hour and $57.58 \%$ in the group treated with dexamethasone $5 \mathrm{mg} / \mathrm{kg}$ bw.

3.3. Effect of Arachic Acid Ethyl Ester (AAEE) on Cotton Pellet-Induced Granuloma Formation in Rats. In the untreated group (control) rats, granuloma formation in rats induced by cotton pellet was $57.2 \pm 3.1 \mathrm{mg}$. In rats treated with the AAEE solution at doses of $12.5 \mathrm{mg} / \mathrm{kg}, 25 \mathrm{mg} / \mathrm{kg}$, and $50 \mathrm{mg} / \mathrm{kg}$ bw or treated with dexamethasone $5 \mathrm{mg} / \mathrm{kg}$ bw, the cotton pellet-induced granuloma formulation significantly reduced $(p<0.01)$ and were $45.3 \pm 2.1 \mathrm{mg}, 36.0 \pm$ $2.2 \mathrm{mg}, 30.2 \pm 1.0 \mathrm{mg}$, and $27 \pm 1 \mathrm{mg}$, respectively (Table 2 ). Maximum inhibitions were $47.4 \%$ in the group treated with AAEE $50 \mathrm{mg} / \mathrm{kg}$ bw at the second hour and $52.6 \%$ in the group treated with dexamethasone $5 \mathrm{mg} / \mathrm{kg} \mathrm{bw}$.

3.4. Analgesic Effect of Arachic Acid Ethyl Ester (AAEE). In the hot plate method, both AAEE and morphine were found to exhibit a dose-dependent increase significantly $(p<0.01)$ in latency time when compared with the control group. The latency period at different times has increased significantly compared to the initial values in the same treated group. The maximal effect of the drug was observed at a dose of $50 \mathrm{mg} / \mathrm{kg}$, which gave a maximal latency time of $26.0 \pm$ $6.8 \mathrm{~s}, 2 \mathrm{~h}$ before administering drugs with a maximal analgesic percentage of $80.62 \%$ similar to morphine $(2.5 \mathrm{mg} / \mathrm{kg})$ with $25.4 \pm 6.8$ s of maximal reaction and an analgesic percentage of $80 \%$ (Table 3 ).

\section{Discussion}

There are two main types of anti-inflammatory drugs: steroidal anti-inflammatory drugs (SAIDs) and nonsteroidal antiinflammatory drugs (NSAIDs) [16]. Nonsteroidal antiinflammatory drugs (NSAIDs) work by inhibiting the activity of the enzyme cyclooxygenase (COX-1 and COX-2) and suppressing the formation of prostaglandins responsible for pain and edema $[17,18]$. Arachic acid ethyl ester was effected
TABLE 2: Effect of arachic acid ethyl ester (AAEE) on cotton pelletinduced granuloma in rats.

\begin{tabular}{lccc}
\hline Group & Treatment & $\begin{array}{c}\text { Granuloma } \\
\text { weight }(\mathrm{mg})\end{array}$ & \% inhibition \\
\hline Control & PO $(10 \mathrm{~mL} / \mathrm{kg})$ & $57.2 \pm 3.1$ & \\
Dexamethasone & $5 \mathrm{mg} / \mathrm{kg}$ & $27.1 \pm 1.2^{* *}$ & 52.6 \\
& $12.5 \mathrm{mg} / \mathrm{kg}$ & $45.3 \pm 2.1^{*}$ & 21.1 \\
AAEE & $25 \mathrm{mg} / \mathrm{kg}$ & $36.0 \pm 2.2^{* *}$ & 36.8 \\
& $50 \mathrm{mg} / \mathrm{kg}$ & $30.2 \pm 1.0^{* *}$ & 47.4 \\
\hline
\end{tabular}

Values are expressed as mean $\pm \operatorname{SEM}(n=5)$. Significant difference: ${ }^{*} p<0.05$ and ${ }^{* *} p<0.01$ compared with control. PO: palm oil.

in a rat model of acute and chronic inflammation as well as analgesic activities.

Carrageenan induces inflammation by the prostaglandins synthesis responsible for pain and edema. Nonsteroidal antiinflammatory agents primarily inhibit the cyclooxygenase involved in the synthesis of these prostaglandins [19]. Carrageenan-induced edema has been commonly used as an animal model for inflammation and is believed to be biphasic [20]. During the early phase of inflammation, damaged and surrounding tissues synthesize mainly mediators such as histamine, serotonin, and a large amount of prostaglandins. The release of these prostaglandins supports the terminal phase of inflammation mediated by bradykinin, leukotrienes, polymorphic nuclear cells, and prostaglandins produced by tissue macrophages [21]. In this study, arachic acid ethyl ester significantly elicited inhibitory effect on edema formation at all assessment time, similar to that exhibited by the group treated with dexamethasone. These results indicate that this compound can act either by inhibiting the synthesis and release of inflammatory mediators such as prostaglandins, histamine, serotonin, and bradykinin or by inhibiting the activity of cyclooxygenase.

Xylene induces inflammation by increasing the activity of phospholipase $A_{2}$ which can be inhibited by topical antiinflammatory steroids or nonsteroidal antiphlogistic agents [22]. This acute model was mediated by histamine, serotonin, and bradykinin. In the present study, the increase in ear weight was dose-dependently inhibited by the arachic acid ethyl ester treatment. This compound would oppose the secretion or action of inflammatory mediators, thereby confirming the anti-inflammatory effect observed during the first phase of carrageenin-induced paw edema in rat [4].

The cotton pellet granuloma model was used to evaluate the activity of ethyl arachidate in chronic inflammation. A cotton pellet implanted subcutaneously in the rat induces inflammation in three phases: the first phase (transudative phase), which lasts about 3 hours, the second phase (exudative phase) which takes place between 3 and 72 hours after the implantation of the pellet, and the third phase (proliferative phase) characterized by the increase in the dry weight of the granuloma and which occurs between 3 days and 6 days after implantation [19], due to proliferation of inflammatory cells like macrophages, neutrophils, and fibroblasts which accumulate at the site implant [23]. In this model, arachic acid ethyl ester effectively inhibited the development of 


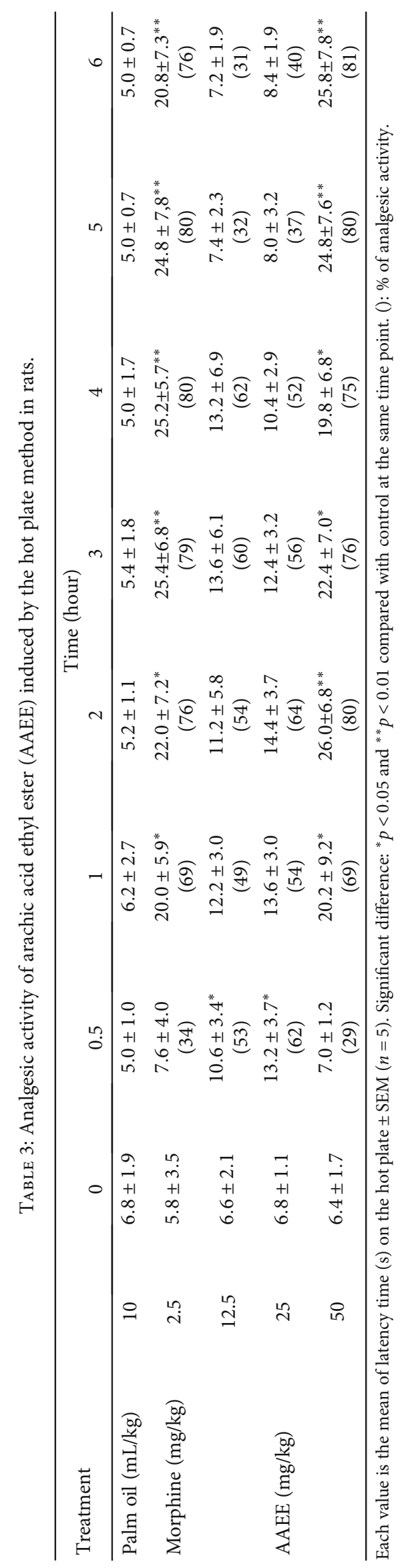


granulomatous tissues compared to control group. This isolated compound may act by inhibiting neutrophils and macrophages migration or by inhibiting fibroblast and the collagen synthesis, which are natural proliferative events of granuloma formation [24].

Rodents' feet are sensitive to heat at temperatures that do not damage the skin. The responses of these rodents to this heat are jumping, removing legs, and/or licking paws [18]. A number of complex processes, such as opiate, noradrenergic, dopaminergic, and serotonergic systems, control pain $[18,19]$. Arachic acid ethyl ester increase considerably latency time of rats on hot plate according all assessment time similar to morphine $(2.5 \mathrm{mg} / \mathrm{kg})$, a reference analgesic opioid which elevated the heat threshold without major inhibitory effect on psychomotor activity [25]. According to the results of this study, we can conclude that this isolated compound possesses centrally acting analgesic by the inhibition of pain sensation.

Arachidonic acid is one of the major polyenoic fatty acids in mammals. It is the precursor of an important group of biologically active compounds such as prostaglandins, prostacyclins, thromboxanes, and leukotrienes which are responsible for the inflammatory process and pain. These were mediated by cyclooxygenase or lipoxygenase [17]. Arachidic acid is a saturated fatty acid which has the same carbon number $\mathrm{C}_{20}$ as the unsaturated arachidonic acid. Ethyl arachidate would acted by competitive inhibition on the cyclooxygenase and lipoxygenase such as NDAIDs.

\section{Conclusion}

Arachic acid ethyl ester would act as an inhibitor of the action of cyclooxygenase and/or lipoxygenase. These results show clearly that the arachic acid ethyl ester, isolated in the propolis, has acute and chronic anti-inflammatory properties as well as central analgesic properties. This justifies the use of propolis in the traditional treatment of pain.

\section{Data Availability}

The data used to support the findings of this study are available from the corresponding author upon request.

\section{Conflicts of Interest}

The authors of this article declare no conflict of interest.

\section{Acknowledgments}

The authors thank the Faculty of Science, University of Ngaoundéré, Cameroon, for providing the necessary support for this study.

\section{References}

[1] K. L. Sreejamole, C. K. Radhakrishnan, and J. Padikkala, “Antiinflammatory activities of aqueous/ethanol and methanol extracts of Perna viridis Linn. in mice," Inflammopharmacology, vol. 19, no. 6, pp. 335-341, 2011.
[2] A. B. Abbas and A. H. Lichtman, "Innate immunity," in Basic immunology. Functions and disorders of the immune system, Saunders, Ed., pp. 4160-4688, Elsevier, 1992.

[3] S. D. Sokeng, J. Koubé, F. Dongmo et al., "Acute and chronic anti-inflammatory effects of the aqueous extract of Acacia nilotica (L.) Del.(Fabaceae) pods," Academia Journal of Medicinal Plants, vol. 1, no. 1, pp. 1-5, 2013.

[4] S. D. Sokeng, E. Talla, V. Jeweldai et al., "Anti-inflammatory effect of Abyssinone V-4' -methyl ether on acute and chronic inflammation models," Hygeia: Journal for Drugs and Medicines, vol. 5, no. 1, pp. 121-128, 2013.

[5] Y. N. Njintang, N. Tatsadjieu, A. Ngakou, D. Danra, and F. N. Tchuenguem-Fohouo, "Antiradical activity and polyphenol content of ethanolic extracts of propolis," International Journal of Biosciences, vol. 4, no. 2, pp. 56-63, 2012.

[6] A. Mbawala, F. N. T. Fohouo, D. Roger, and J. B. Milliere, "Spectra of antibacterial activity of propolis (Promax-C) samples from two localities of Adamaoua Province (Cameroon)," Research Journal of Microbiology, vol. 4, no. 4, pp. 150-157, 2009.

[7] K. Ghedira, P. Goetz, and R. le Jeune, "Propolis," Phytothérapie, vol. 7, no. 2, pp. 100-105, 2009.

[8] A. H. Banskota, T. Nagaoka, L. Y. Sumioka et al., "Antiproliferative activity of the Netherlands propolis and its active principles in cancer cell lines," Journal of Ethnopharmacology, vol. 80, no. 1, pp. 67-73, 2002.

[9] T. Murata, "Analysis of fatty acid methyl esters by a gas-liquid chromatography-chemical ionization mass spectrometry computer system," Journal of Lipid Research, vol. 19, no. 2, pp. $166-171,1978$.

[10] J. García-Olmo, A. Garrido-varo, and E. De Pedro, "Classification of real farm conditions Iberian pigs according to the feeding regime with multivariate models developed by using fatty acids composition or NIR spectral data," Grasas Y Aceites, vol. 60, no. 3, pp. 233-237, 2009.

[11] J. A. Smith, F. A. R. van den Broek, J. C. Martorell, H. Hackbarth, O. Ruksenas, and W. Zeller, "FELASA Working Grp, and 'Principles and Practice in Ethical Review of Animal Experiments across Europe: Summary of the Report of a Felasa Working Group on Ethical Evaluation of Animal Experiments," Laboratory Animals, vol. 41, no. 2, pp. 143-160, 2016.

[12] C. A. Winter, E. A. Risley, and G. W. Nuss, "Carrageenininduced edema in hind paw of the rat as an assay for antiinflammatory drugs," in Proceedings of the society for experimental Biology and Medicine, pp. 544-547, 1962.

[13] B. C. A. Winter and C. C. Porter, "Effect of alterations in side chain upon anti-inflammatory and liver glycogen activities of hydrocortisone esters," Journal of the Americam Pharmaceutical Association, vol. 46, no. 9, pp. 515-519, 1957.

[14] E. A. Asongalem, H. S. Foyet, J. Ngogang, G. N. Folefoc, T. Dimo, and P. Kamtchouing, "Analgesic and antiinflammatory activities of Erigeron floribundus," Journal of Ethnopharmacology, vol. 91, no. 2-3, pp. 301-308, 2004.

[15] I. Aouissa, Study of biological activities and acute toxicity of aqueous extract of leaves of Mangifera indica Linn (Anacardiaceae), Department of Pharmacy, University of Bamako, Mali, 2002.

[16] R. O. Onzago, S. G. Kiama, J. M. Mbaria, D. W. Gakuya, C. G. Githiji, and Z. M. Rukenya, "Analgesic activity of aqueous extract of Vernonia hymenolepis (A. Rich) a traditional medicine plant used in Kenya for toothache," The Journal of Phytopharmacology, vol. 2, no. 6, pp. 41-45, 2013. 
[17] F. Oesch and M. Arand, "Xenobiotic metabolism," in Toxicology, H. Marquardt, S. G. Schäfer, R. McClellan, and F. Welsch, Eds., pp. 83-109, Elsevier Inc., 1999.

[18] D. Mishra, G. Ghosh, P. S. Kumar, and P. K. Panda, "An experimental study of analgesic activity of selective COX-2 inhibitor with conventional NSAIDs," Asian Journal of Pharmaceutical and Clinical Research, vol. 4, no. 1, pp. 78-81, 2011.

[19] A. M. Vittalrao, T. Shanbhag, K. M. Kumari, K. L. Bairy, and S. Shenoy, "Evaluation of antiinflammatory and analgesic activities of alcoholic extract of Kaempferia galanga in rats," Indian Journal of Physiology and Pharmacology, vol. 55, no. 1, pp. 13-24, 2011.

[20] O. A. Olajide, S. Awe, J. Makinde et al., "Studies on the antiinflammatory, antipyretic and analgesic properties of Alsotinia boone stem bark," Journal of Ethnopharmacology, vol. 71, no. 1-2, pp. 179-186, 2000.

[21] J. Estakhr, F. Javadian, Z. Ganjali, M. Dehghani, and A. Heidari, "Study on the anti-inflammatory effects of ethanolic extract of Cynanchum acutum," Current Research Journal of Biological Sciences, vol. 4, no. 5, pp. 630-632, 2012.

[22] K.-H. Cho, H. D. Kim, B. W. Lee, M. K. Lim, and S. K. Ku, "Effects of magnetic infrared laser on xylene-induced acute inflammation in mice," Journal of Physical Therapy Science, vol. 20, no. 4, pp. 255-259, 2008.

[23] S. Tripathy, D. Pradhan, and M. Anjana, "Anti-inflammatory and antiarthritic potential of Ammania baccifera Linn.," International Journal of Pharma and Bio Sciences, vol. 1, no. 3, pp. 1-7, 2010.

[24] A. Lewis, D. Gemmell, and W. Stimson, "The antiinflammatory profile of dapsone in animal models of inflammation," Agents and Actions, vol. 8, no. 6, pp. 578-586, 1978.

[25] M. Boros, R. Benkó, K. Bölcskei, J. Szolcsányi, L. Barthó, and G. Pethő, "Effects of Reference Analgesics and Psychoactive Drugs on the Noxious Heat Threshold of Mice Measured by an Increasing-Temperature Water Bath," Basic \& Clinical Pharmacology \& Toxicology, vol. 113, no. 6, pp. 385-390, 2013. 